\title{
Exploring The Use of Literacy Strategies in Junior High School Level
}

\author{
Kisyani-Laksono, P. Retnaningdyah \\ Universitas Negeri Surabaya, Indonesia \\ kisyani@unesa.ac.id
}

\begin{abstract}
The 2013 Indonesian curriculum requires that literacy be incorporated into teaching learning process. This paper aims to (1) identify literacy strategies that have and not have been planned in learning steps; (2) identify literacy strategies that were used in teaching practice sessions. The data were taken from lesson plans developed by teachers of fifteen subjects in Junior High School level. Observations of teachers' teaching practices were carried out to examine what literacy strategies were used during the teaching learning process. Interviews with several teachers were also conducted to gain further explanation why certain literacy strategies were absent in the teaching practice. The results of the study demonstrate that teachers of fifteen subjects have used various literacy strategies in their lesson plans and teaching practice. However, most teachers have not explicitly mentioned the following strategies: making and confirming prediction, identifying new and difficult vocabularies, using other sources, making a connection with other texts, transforming mode, producing multimodal texts, and using graphic organizers. The findings imply that more intensive teacher professional development programmes provide modelling and explicit instruction of how to implement literacy strategies in the classroom.
\end{abstract}

\section{Keywords—literacy strategies; junior high school}

\section{INTRODUCTION}

Literacy is inseparable from the world of education. Literacy becomes a means for students to know, understand, and apply the knowledge acquired in school. Literacy is also related to student's life, both at home and in the surrounding environment to cultivate noble character. Literacy originally meant 'reading and writing' and was subsequently interpreted as 'an ability to understand'. In the first step, "reading and writing literacy" is emphasized because both language skills are the basis for the development of literacy in a variety of ways.

Literacy learning involves an understanding of multiliteracies. According to the World Economic Forum (2016), learners need sixteen skills to survive in the $21 \mathrm{st}$ century, namely basic literacy (how students apply the skills for everyday life), competence (how students respond to complex challenges), and character (how learners meet changes in their environment).

The term literacy is something that continues to grow and process. Nonetheless, literacy skills pivot on an understanding of the text and the context because human beings deal with documents throughout their lives from birth to death. Understanding of various texts will help us understand various aspects of our lives since documents represent the life of individuals and communities in their respective cultures.

Indonesian schools have not yet developed literacy skills in the classroom context. This is partly caused by a lack of understanding of the importance of literacy capabilities in student's life and a lack of use of sources other than school textbooks. In other words, reading in schools is still limited to reading textbooks. Moreover, the term school literacy is still incorrectly understood merely as the 15 -minute reading time before class.

Meanwhile, the results of several international tests have shown that students' literacy level in Indonesia is still far from being satisfactory. The 2011 PIRLS or Progress of International Reading Literacy Study (PIRLS) that evaluated the reading literacy of fourth graders indicated that Indonesia ranked 42 nd of 45 participating countries. In a similar vein, the 2015 PISA, or Program for International Student Assessment that evaluated the ability of 15-year-old students in reading, math, and science placed Indonesia at rank 64th of 70 countries. The result of IN-AP or Indonesian National Assessment Program that evaluates students' abilities in reading, math, and science is also parallel to PIRLS (46.83\% of students scored below standard in reading competence). Moreover, the result of the 2016 Program for the International Assessment of Adult Competencies (PI-AAC) was unsatisfactory. Indonesia ranked at the bottom in virtually all types of adult competencies necessary to work and work as a member of society (OECD, 2016). Such condition is worrying because the ability, and reading skills are the basis for the acquisition of knowledge, skills, and forming attitudes.

To respond to this literacy crisis, the Directorate of Primary and Secondary Education established Literacy Movement School (in Indonesia: Gerakan Literasi Sekolah) in 2016 as a strategy to develop student's character by fostering reading so as to create lifelong learners [18].

Several guidebooks of School Literacy Movement were published by the Directorate of Primary and Secondary Education in 2016, namely (1) Grand Design of School Literacy Movement, (2) Guidebook of School Literacy Movement for Primary Schools, (3) Guidebook of School Literacy Movement for Junior High Schools, (4) Guidebook of School Literacy Movement for Senior High Schools, (5) Guidebook of School Literacy Movement for Vocational High Schools; (6) Guidebook of School Literacy Movement for Special Education, (7) Pocket book of School Literacy 
Movement, and (8) Manual for School Literacy Movement for Junior High Schools.

Using those guidebooks, the Ministry of Education and Culture conducted a nationwide teachers' professional development programme to train teachers from various provinces to implement the revised version of the 2013 curriculum. One of the objectives of the program was to train teachers of all subjects to employ literacy strategies in the classroom. It was expected that teachers would be able to enrich their teaching learning process so as to improve students' literacy skills and develop the 21 stcentury skills. This paper presents the findings of the implementation of literacy strategies by Junior High School teachers who teach various subjects in their lesson plans and teaching practices during the training.

The primary purpose of using literacy strategies is to build understanding, writing skills and overall communication skills. Thus far, the most commonly accepted notion is that literacy is needed only in language learning or language classes. This concept is certainly not by for increasing attention to literacy in math, science, social sciences, engineering, arts, sports, health, economics, religious studies, crafts, etc. [13]. Content learning is what is taught, while literacy is more about how to teach content areas. Therefore, practically all subjects taught at school require literacy strategies to be implemented in the teaching learning process. A number of studies suggest that literacy strategies in content area learning help students to think critically, solve problems, and improve language skills [9], develop a better sense of citizenship [8], and improve student behavior $[12,16]$.

The learning process that applies essential literacy strategies also cultivates good and critical readers. Scholars suggest the following characteristics of literacy strategies to develop metacognitive skills $[11,1]$.

1) Text comprehension monitoring (recording student understanding before, while, and after reading).

2) using various modes of learning (multimodal literacies),

3) using clear and explicit instructions,

4) using graphic organizers,

5) responding to various types of questions,

6) making inquiries,

7) analyzing, synthesizing, and evaluating the text,

8) summarizing the text.

The above literacy strategies also suggest the possibility to implement them in various learning models such as cooperative learning, text-based, project-based, problem-based, inquiry, discovery, and scientific approach, depending on the characteristics of the subjects and competencies to be achieved in the lesson $[13,17,1,5,19]$.

\section{METHOD}

The data in this paper include lesson plans written by teachers of fifteen subjects taught at Junior High School, namely: Islamic Studies, Catholic Studies, Christian studies, Hindu Studies, Buddhist Studies, Confucius Studies, Indonesian Language, English, Science, Math, Social Studies, Arts, Crafts, Civics, and Physical Education. The learning steps of the collected lesson plans were analyzed by using an instrument of literacy strategies to check what literacy strategies are explicitly stated in the plans. The same instrument was also used to observe teachers' teaching practices during the training with the purpose to check what literacy strategies were implemented. Furthermore, interviews with several teachers were conducted to find out why teachers did not explicitly state certain literacy strategies in their lesson plans.

\section{RESULT AND DISCUSSIONS}

The present study investigated the implementation of the literacy strategies in two stages. In the first stage, the learning steps of lesson plans that the teachers prepared were examined. In the later stage, the use of literacy strategies in learning was observed during the teaching learning process at the teaching practice session of the training program. The follow-ing table presents the recapitulation of the use of literacy strategies $(\mathrm{NLP}=$ number of lesson plans).

TABLE I. LITERACY STRATEGIES

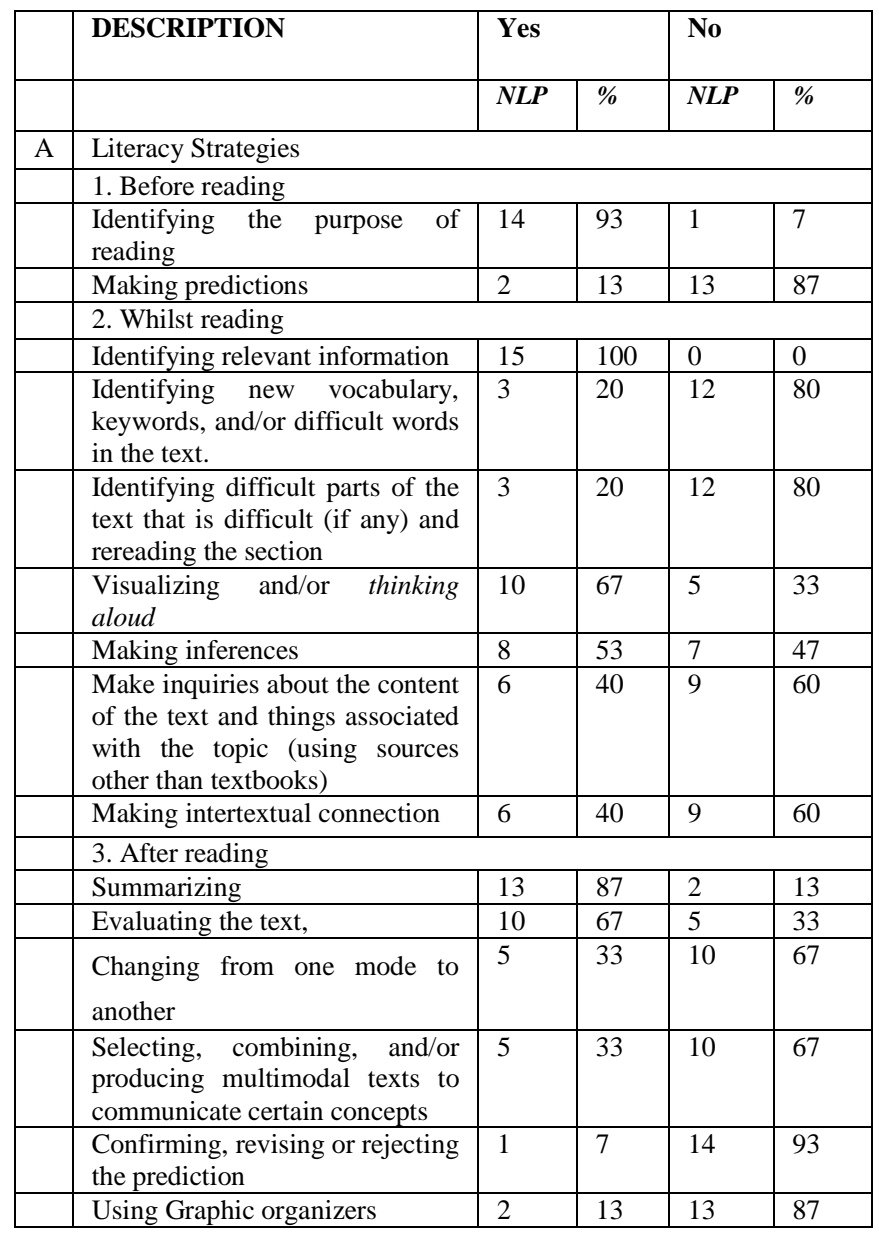


In the above table, the literacy strategies are distributed in three stages--before reading, while reading, and after reading. The analysis of teachers' lesson plans and observation of the teaching-learning process during the teaching practice session indicate that most teachers already incorporated literacy strategies both in their lesson plans and teaching practice session to various extent. All teachers stated the importance of identifying the purpose of learning both in lesson plans and teaching practice session. However, during the group interview, they commented on the inclusion of purpose of learning not based on their awareness of the strategy as part of literacy strategies. Instead, mentioning the purpose of learning or reading is considered compulsory in any format of lesson plans. In a similar vein, 14 teachers indicated the use the strategy of identifying relevant information both in their lesson plans and in the teaching practice session. The interview also revealed that all teachers felt relief to learn that they had been using literacy strategies without an explicit knowledge of the term. This confirms that literacy strategies are compatible with various learning models that teachers apply.

The above table also indicates that most teachers in the study have not explicitly stated some literacy strategies, such as making predictions, with $87 \%$ stating NO, confirming prediction (93\% stating NO) identifying new and challenging vocabulary /word ( $80 \%$ stating NO), the use of resources other than textbooks and making intertextual connection $(60 \%$ stating NO), changing from one mode to another and producing multimodal texts (67\% stating NO). Moreover, $87 \%$ of teachers did not explicitly use graphic organizers in their lesson plans and teaching practice.

These findings imply that teachers need to be given more intensive training on the importance of explicit instruction. As suggested in the Multiliteracies pedagogy, overt instruction is an essential element in any learning process [3,11]. The strategy of making predictions can be included in the apperception stage of as students will be able to associate the content to be learned with their prior knowledge. Moreover, the use of graphic organizers is deemed essential to assist students in visualizing what they are learning. A number of studies clearly suggest that using graphic organizers helps improve students' metacognitive skills [14,6,4]. In the present study, while the training program was already equipped with a module that provides examples of graphic organizers for content area learning, most teachers were still not sure about the uses and benefits in the classroom. It was only during the interview that followed the teaching practice session that teachers learned about the benefits after directly experiencing the use of literacy strategies in their teaching practice session.

Another important thing to discuss further is teachers' lack of understanding of the importance of considering new and challenging words in the text. Most teachers admitted that they assumed that it is the student's responsibility to find out the meaning of new and challenging words from the dictionary. Some recommended the use of the internet to find the meaning of new terms. However, most teachers were not aware that context clues were more efficient. This implies that teachers also need clearer modeling of how to teach students to use context clues for new and challenging vocabularies.
It should be noted that most teachers still tend to assume that literacy has to do only with printed text. They were not yet familiar with the concept of multimodal texts. As a result, the strategy of changing from one mode to another was still not incorporated into teachers' lesson plans and teaching practice session. On the other hand, today's children's lives are surrounded by texts in various modes-print, audio, visual, audiovisual, tactile, and digital. Various studies confirm that multimodal literacies need to be incorporated into teaching learning process to develop students' higher-order thinking skills and, thus, prepare them to be more information literate [20,15,2].

This strategy is not complicated but requires creativity. For instance, changing modes from a descriptive text to a concept map, from a narrative to a table, or from a story to a visual representation will greatly help students to focus on something. Multi-modal texts will also enhance students' creativity and train higher-order level thinking skills. Once again, this finding suggests a more intensive training of how to use literacy strategies in the teaching-learning process.

\section{CONCLUSION}

Learning that is enriched with literacy strategies is expected to foster students' critical thinking skills, creative thinking, collaborative and communicative skills, good character, higher order thinking skills, and metacognitive intelligence. The present study indicates that teachers positively embrace the need to use literacy strategies in lesson plans and teachinglearning process, but have not fully integrated the strategies. Most teachers have not explicitly employed the strategies of making and confirming predictions, identifying new and challenging vocabularies, using texts other than textbooks, making the connection between texts, transforming one mode to another, and using graphic organizers. These findings are parallel both in lesson plans and teaching practice. This implies that most teachers still lack an understanding of the importance of literacy strategies as scaffolding strategies in developing higher-order thinking skills. Therefore, the study recommends that more intensive training and supervision that focus on developing literacy strategies be given to assist teachers in improving their teaching profession.

\section{REFERENCES}

[1] C.S. Beers, J.W. Beers and J.O. Smith, A principal's guide to literacy instruction, New York: Guilford Press, 2010.

[2] D. Clary, M. Kigotho, and M. Barros-Tornin, "Harnessing mobile technologies to enrich adolescents' multimodal literacy practices in middle years." Literacy Learning vol. 21, no. 3, pp. 49-60, 2013.

[3] B. Cope and M. Kalantzis (Eds), Multiliteracies: Literacy learning and the design of social futures. London: Routledge, 2000.

[4] C.C. Lee and S.C. Tan, "Scaffolding writing using feed-back in students' graphic organizers - novice writers' rele-vance of ideas and cognitive loads." Educational Media International, vol. 47, no. 2, pp. 135-152, 2010.

[5] C. Greenleaf, et al, "Integrating literacy and science in Biology: Teaching and learning impacts of reading appren-ticeship professional development." American Educational Research Journal, vol. 48, no. 3, pp. 647-717, 2011.

[6] L. Key, J.A. Bradley and K.S. Bradley, "Stimulating in-struction in Social Studies.” The Social Studies, vol. 101, pp. 117-120, 2010. 
[7] Kisyani-Laksono et al, Manual pendukung gerakan literasi sekolah untuk Sekolah Menengah Pertama. Jakarta: Direktorat PSMP, Dikdasmen, Kemdikbud, 2016.

[8] D.A. MacPhee, and E.J. Whitecotton, "Bringing the "social" back to Social Studies: Literacy strategies as tools for un-derstanding history." Social Studies, vol. 102, no. 6, pp. 263-267, 2011.

[9] K. Ming, "10 content-area literacy strategies for Art, Mathematics, Music, and Physical Education." The Clear-ingHouse, 85 (6): 213-220, 2012.

[10] OECD, The Survey of Adult Skills: Reader's Companion, Second Edition. OECD Studies, 2016.

[11] K. Pahl and J. Rowsell, Literacy and education, London: Paul Chapman Publishing, 2005.

[12] S. Reeves and B. Stanford, "Blending technology and literacy strategies: Engaging learners with emotional or be-havioral disorders." Journal of Special Education Tech-nology, vol. 24, no. 2, pp. 42-45, 2009.

[13] L. Robb, Teaching reading in Social Studies, Science, and Math: Practical ways to weave comprehension strate-gies into your content area teaching, New York: Scholastic Professional Books, 2003.
[14] D.H. Robinson, et al, "Increasing text comprehension and graphic note taking using a partial graphic organizer." The Journal of Education Research, vol. 100, no. 2, pp. 103-111, 2006.

[15] W. Sewell, et al, "Multimodal literacies in the secondary English classroom.” English Journal, vol. 100, no. 5, pp. 61-65, 2011.

[16] J. Smith, "Blending effective behavior management and literacy strategies for preschoolers exhibiting negative be-havior." Early Childhood Educ J, vol. 37, pp. 147-151, 2009.

[17] R.E. Toolin, "Striking A balance between innovation and standards: A study of teachers implementing project-based approaches to teaching science." Journal of Science Edu-cation and Technology, vol. 13, no. 2, pp. $179-187,2004$.

[18] Wiedarti, Pangesti and Kisyani-Laksono (ed.), Desain induk gerakan literasi sekolah. Jakarta: Dikdasmen, Kemdikbud, 2016.

[19] A.A. Wilson and K.J. Chavez, Reading and representing across the content areas: A Clasroom Guide, New York: Teachers College Press, Columbia University, 2014.

[20] L. Unsworth and E. Chan, "Bridging multimodal literacies and national assessment programs in literacy." The Australian Journal of Language and Literacy, vol. 32, no. 3, pp. 245-257, 2009. 